Gut, 1978, 19, 284-289

\title{
Pathophysiological responses to meals in the Zollinger-Ellison syndrome: 1. Paradoxical postprandial inhibition of gastric secretion ${ }^{1}$
}

\author{
J.-R. MALAGELADA ${ }^{2}$ \\ From the Gastroenterology Unit, Mayo Clinic and Mayo Foundation, Rochester, USA
}

SUMMARY The gastric acid, pepsin, and secretory volume output in response to a mixed meal were measured in six patients with Zollinger-Ellison syndrome caused by a gastrin-producing tumour proved subsequently at surgery. The patients were all normocalcaemic, and none had previous abdominal surgery. In four of the six patients, ingestion of the meal markedly inhibited the gastric secretory output, which decreased to below fasting levels, returning later to basal values. In two other patients, whose fasting acid output was considerably lower, the secretory output increased after the meal, but some inhibition of gastric secretion was also apparent for variable intervals of time. The serum gastrin concentration in all patients remained essentially unchanged or increased after the meal. Two patients were restudied after successful removal of the duodenal gastrin-producing tumour, and in each the normal gastric secretory and gastrin-releasing responses were completely restored. Our studies suggest that, in patients with the Zollinger-Ellison syndrome caused by a gastrinoma, physiological regulatory mechanisms triggered by food reduce the continuous stimulation of gastric secretion caused by their tumoural hypergastrinaemia.

The gastric secretory response to meals in the Zollinger-Ellison (Z-E) syndrome was studied in order to observe: (1) the effects of sustained, endogenous hypergastrinaemia on postprandial gastric function, and (2) interactions between hypergastrinaemia and other neurohormonal mechanisms activated by ingestion of food. By a method previously developed and validated (Malagelada et al., 1976b), we measured gastric secretory responses to a mixed meal in a group of six patients with gastrinoma; two of the six were also studied after successful excision of the gastrin-producing tumour.

\section{Methods}

PATIENTS

The six patients with the Z-E syndrome fulfilled the criteria of fasting gastric hyperchlorhydria (Figs. 1 and 2), hypergastrinaemia (Table 1), and biopsy-

'Supported in part by Grant AM-6908 from the National Institutes of Health.

${ }^{2}$ Address for reprint requests: Dr J.-R. Malagelada, Mayo Clinic, Rochester, MN 55901, USA.

Received for publication 19 October 1977 proved diagnosis of endocrine-type tumour at surgery. All six patients were normocalcaemic, and none had previous abdominal surgery. No patient had clinical or radiographic evidence of gastric outlet obstruction, and none was receiving anticholinergic drugs or $\mathbf{H}_{2}$-receptor inhibitor drugs. The use of oral neutralising antacids was stopped at least six hours before the study was started. Our investigations began after securing approval from the Mayo Clinic Human Studies Committee (23 March 1974), and informed consent was also obtained from every patient. The patients' clinical histories and laboratory data are summarised in Table 2. Subsequent follow-up of case 1 (up to nine months) and of case 2 (up to three years), who were restudied after excision of their gastrin-secreting tumours, has revealed no recurrence of hypergastrinaemia, gastric hypersecretion, or clinical symptoms.

MEASUREMENT OF POSTPRANDIAL GASTRIC SECRET ORY OUTPUTS

We used our method for the measurement of gastric acid, pepsin, and secretory volume outputs after a meal (Malagelada et al., 1976b). In brief, patients 

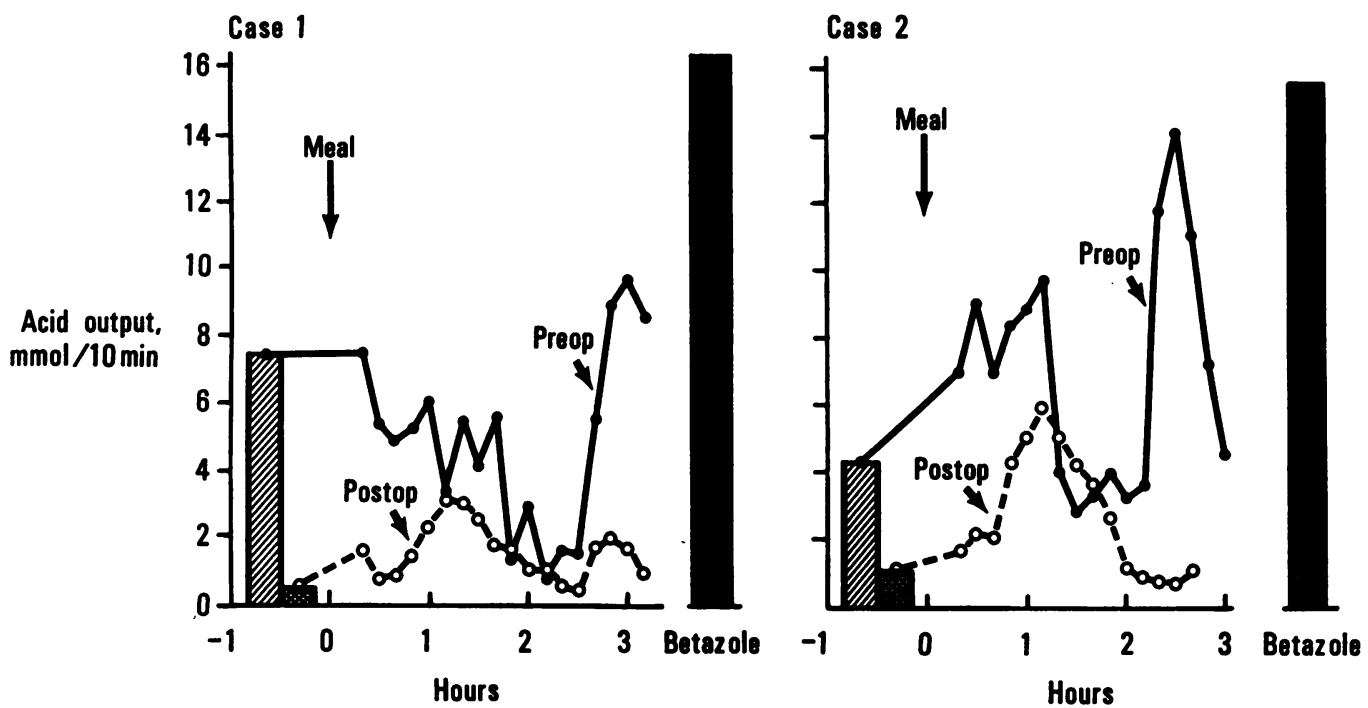

Fig. 1 Gastric acid output in patients with gastrinoma (cases 1 and 2). Key to Figs. 1 and 2: shaded and stippled bars: basal (fasting) acid outputs measured during the hour before ingestion of the meal; black bar: peak betazole-stimulated acid outputs. Gastric acid outputs after excision in these two patients of a duodenal gastrin-producing tumour are also shown.
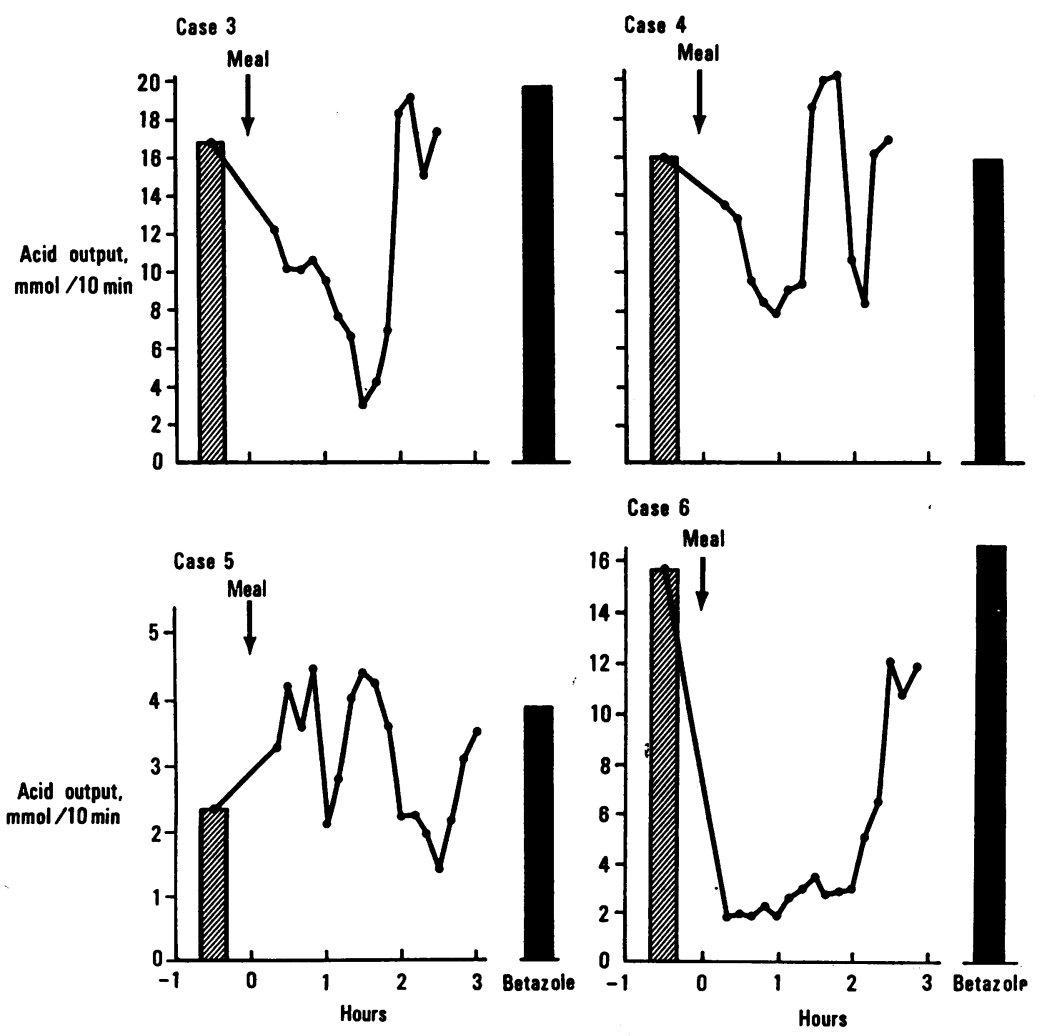

Fig. 2 Gastric acid output in patients with gastrinoma (cases 3 to 6). Key as in Fig. 1. 
Table 1 Serum immunoreactive gastrin concentrations before and after meals in patients with gastrinoma

\begin{tabular}{|c|c|c|c|c|c|c|c|c|}
\hline \multirow[t]{3}{*}{ Case } & \multicolumn{8}{|c|}{ Serum immunoreactive gastrin concentrations $(\mathrm{pg} / \mathrm{ml})$} \\
\hline & \multicolumn{8}{|c|}{ Time postprandially (min) } \\
\hline & -30 & -5 & +15 & +45 & +75 & +105 & +135 & +165 \\
\hline 1 & 726 & 512 & 1014 & 564 & 498 & 594 & 558 & 610 \\
\hline 2 & 398 & 368 & 382 & 431 & 351 & 353 & 427 & 407 \\
\hline 3 & 1353 & 1290 & 1930 & 3310 & 2227 & 2153 & 1700 & 1290 \\
\hline 5 & 1765 & 2080 & 2630 & 5540 & 5140 & 4133 & 2647 & 2840 \\
\hline 6 & 434 & 413 & 516 & 510 & 471 & 390 & 357 & 367 \\
\hline $1 *$ & 88 & 55 & 80 & 124 & 113 & 121 & 98 & 105 \\
\hline $2^{*}$ & 124 & 126 & 227 & 145 & 197 & 189 & 138 & 129 \\
\hline
\end{tabular}

* Repeat studies after excision of gastrin-producing tumour.

Table 2 Clinical data

\begin{tabular}{|c|c|c|c|c|c|c|c|c|c|}
\hline \multirow[t]{2}{*}{ Case } & \multirow{2}{*}{$\begin{array}{l}\text { Age } \\
\operatorname{sex}\end{array}$} & \multirow{2}{*}{$\begin{array}{l}\text { Height } \\
(\mathrm{cm})\end{array}$} & \multirow{2}{*}{$\begin{array}{l}\text { Weight } \\
(k g)\end{array}$} & \multicolumn{3}{|c|}{ Clinical history } & \multirow[t]{2}{*}{ Endoscopic findings } & \multicolumn{2}{|l|}{ Surgery } \\
\hline & & & & $\begin{array}{l}\text { Duration } \\
(y r)\end{array}$ & GIsymptoms & $M E A$ & & $\begin{array}{l}\text { Endocrine-type } \\
\text { neoplasia }\end{array}$ & Procedure \\
\hline $\begin{array}{l}1 \\
2 \\
3 \\
4\end{array}$ & $\begin{array}{l}63 \mathrm{M} \\
57 \mathrm{~F} \\
36 \mathrm{M} \\
13 \mathrm{M}\end{array}$ & $\begin{array}{l}166 \cdot 4 \\
168 \cdot 6 \\
187 \cdot 0 \\
151 \cdot 1\end{array}$ & $\begin{array}{r}82 \cdot 7 \\
56 \cdot 8 \\
114 \cdot 1 \\
50 \cdot 0\end{array}$ & $\begin{array}{c}4 \mathrm{~m} \\
10 \\
5 \\
2\end{array}$ & $\begin{array}{l}\text { Pain, melaena } \\
\text { Pain, diarrhoea } \\
\text { Pain, diarrhoea } \\
\text { Pain }\end{array}$ & $\begin{array}{l}\text { No } \\
\text { No } \\
\text { No } \\
\text { No }\end{array}$ & $\begin{array}{l}\text { Erosive duodenitis } \\
\text { Erosive duodenitis } \\
\text { Erosive duodenitis } \\
\text { Duodenal ulcer } \\
\text { (multiple) }\end{array}$ & $\begin{array}{l}\text { Duodenal wall } \\
\text { Duodenal wall } \\
\text { Pancreas } \\
\text { Liver metastasis }\end{array}$ & $\begin{array}{l}\text { TEO } \\
\text { TEO } \\
\text { TG } \\
\text { TG }\end{array}$ \\
\hline $\begin{array}{l}5 \\
6\end{array}$ & $\begin{array}{l}34 \mathrm{~F} \\
38 \mathrm{M}\end{array}$ & $\begin{array}{l}165 \cdot 0 \\
170 \cdot 2\end{array}$ & $\begin{array}{l}88 \cdot 2 \\
87 \cdot 7\end{array}$ & $\begin{array}{r}20 \\
3\end{array}$ & $\begin{array}{l}\text { Pain } \\
\text { Pain }\end{array}$ & $\begin{array}{l}\text { Yes } \\
\text { No }\end{array}$ & $\begin{array}{l}\text { Duodenal ulcer } \\
\text { Duodenal ulcer }\end{array}$ & $\begin{array}{l}\text { Pancreas } \\
\text { Mediastinum }\end{array}$ & $\begin{array}{l}\text { TG } \\
\text { TEO }\end{array}$ \\
\hline
\end{tabular}

MEA : multiple endocrine adenomatosis. TEO: tumour excision only. TG: total gastrectomy.

were intubated with double-lumen gastric and duodenal tubes. A ${ }^{14} \mathrm{C}$ polyethylene glycol solution in normal saline was perfused at a constant rate of $2 \mathrm{ml} / \mathrm{min}$ into the second duodenal portion, and contents were aspirated $20 \mathrm{~cm}$ distally at the level of the angle of Treitz. A mixed meal consisting of $90 \mathrm{~g}$ cooked tenderloin steak, $25 \mathrm{~g}$ white bread, $8 \mathrm{~g}$ butter, $60 \mathrm{~g}$ vanilla ice cream, $35 \mathrm{~g}$ chocolate syrup, $0.1 \mathrm{~g}$ salt, and water (up to $400 \mathrm{ml}$ total volume) was thoroughly homogenised (Waring blender) at $37^{\circ} \mathrm{C}$. The total caloric value of 458 calories was distributed approximately as $40 \%$ carbohydrate, $40 \%$ fat, and $20 \%$ protein; the pH was 6.0 , and the osmolality was $540 \mathrm{mosm} / \mathrm{kg}$. After determination of the 'basal' gastric secretory rate as detailed later, the meal was delivered intragastrically over a 10minute period. During the next three hours, gastric and duodenal samples were obtained and were analysed for markers, acid, and pepsin (Malagelada et al., 1976b). Blood samples were obtained at regular intervals (Table 1) and were analysed for serum immunoreactive gastrin concentrations (Sizemore et al., 1973). Calculations previously described in detail were employed to obtain postprandial gastric acid, pepsin, and total secretory volume outputs (Malagelada et al., 1976b). Peak postprandial secretory outputs were calculated by doubling the sum of the three consecutive highest 10-minute outputs, and lowest postprandial secretory outputs were estimated by doubling the sum of the three consecutive lowest 10-minute outputs (Table 3). Two patients, whose tumours were resected and whose fasting serum gastrin levels returned to normal after the procedure, were restudied after the fourth postoperative week.

MEASUREMENT OF BASAL AND PEAK (BETAZOLE-STIMULATED) GASTRIC ACID OUTPUT On a separate day, 'basal' acid output and 'maximal' response to betazole (Isenberg, 1973) were determined by the standard method of continuous gastric perfusion (Malagelada et al., 1976a) employing ${ }^{51} \mathrm{CrCl}_{3}$ as a recovery marker. After continuous perfusion and aspiration for at least 30 minutes to achieve steady state conditions, four 15-minute collections were made during the basal period. This was followed by seven 15-minute collections, after the subcutaneous injection of betazole $(1.5 \mathrm{mg} / \mathrm{kg}$ body weight). The results were expressed as basal acid output (mmol of acid secreted per one hour) and maximal acid output (mmol/h) obtained by doubling the outputs during the two highest consecutive 15 -minute periods after betazole administration.

Therefore, in each patient, two basal secretion measurements were performed on different days: 
Table 3 Fasting and postprandial gastric acid $(A)$, pepsin $(P)$, and volume $(V)$ secretory outputs in patients with gastrinoma

\begin{tabular}{|c|c|c|c|c|c|c|c|c|c|c|c|c|c|c|c|}
\hline \multirow[t]{3}{*}{ Case } & \multicolumn{15}{|c|}{ Gastric secretory outputs in Z-E syndrome } \\
\hline & \multicolumn{5}{|c|}{ Basal output (fasting) } & \multicolumn{5}{|c|}{ Lowest postprandial output } & \multicolumn{5}{|c|}{ Peak postprandial output } \\
\hline & $\begin{array}{l}\text { Acid } \\
(\mathrm{mmol} / \mathrm{h})\end{array}$ & $\begin{array}{l}\text { Pepsin } \\
(m g / h)\end{array}$ & $\begin{array}{l}\text { Volume } \\
(l / h)\end{array}$ & $\boldsymbol{A} ! \boldsymbol{P}$ & $A / V \times 10^{2}$ & $\begin{array}{l}\text { Acid } \\
\text { (mmol!h) }\end{array}$ & $\begin{array}{l}\text { Pepsin } \\
(m g / h)\end{array}$ & $\begin{array}{l}\text { Volume } \\
(l / h)\end{array}$ & $A / P$ & $A / V \times 10^{2}$ & $\begin{array}{l}\text { Acid } \\
(\mathrm{mmol} / \mathrm{h})\end{array}$ & $\begin{array}{l}\text { Pepsin } \\
(m g / h)\end{array}$ & $\begin{array}{l}\text { Volume } \\
(l / h)\end{array}$ & $A / P$ & $A / V \times 10^{2}$ \\
\hline $\begin{array}{l}1 \\
2 \\
3 \\
4 \\
5 \\
6 \\
\text { Mean } \\
1^{*} \\
2^{*}\end{array}$ & $\begin{array}{r}43.9 \\
25.9 \\
102.0 \\
96.2 \\
14.6 \\
94 \cdot 1 \\
62.8 \\
3.0 \\
6.8\end{array}$ & $\begin{array}{r}166 \\
103 \\
182 \\
295 \\
63 \\
706 \\
253 \\
42 \\
77\end{array}$ & $\begin{array}{l}0.42 \\
0.40 \\
0.89 \\
0.83 \\
0.19 \\
1.19 \\
0.65 \\
0.06 \\
0.09\end{array}$ & $\begin{array}{l}0.26 \\
0.25 \\
0.56 \\
0.33 \\
0.23 \\
0.13 \\
0.29 \\
0.07 \\
0.09\end{array}$ & $\begin{array}{l}1.04 \\
0.65 \\
1.15 \\
1.16 \\
0.77 \\
0.79 \\
0.93 \\
0.50 \\
0.76\end{array}$ & $\begin{array}{c}8 \cdot 4 \\
23 \cdot 4 \\
25 \cdot 4 \\
51 \cdot 0 \\
11 \cdot 7 \\
10 \cdot 0 \\
21 \cdot 6 \dagger \\
4 \cdot 1 \\
7 \cdot 4\end{array}$ & $\begin{array}{c}56 \\
66 \\
75 \\
204 \\
31 \\
51 \\
81 \dagger \\
65 \\
65\end{array}$ & $\begin{array}{l}0.06 \\
0.15 \\
0.29 \\
0.44 \\
0.11 \\
0.09 \\
0.19 \ddagger \\
0.06 \\
0.08\end{array}$ & $\begin{array}{l}0.15 \\
0.36 \\
0.34 \\
0.25 \\
0.38 \\
0.20 \\
0.28 \\
0.06 \\
0.11\end{array}$ & $\begin{array}{l}1.40 \\
1.56 \\
0.87 \\
1.16 \\
1.06 \\
1.11 \\
1.19 \\
0.68 \\
0.92\end{array}$ & $\begin{array}{r}54 \cdot 2 \\
72 \cdot 4 \\
104 \cdot 0 \\
120 \cdot 0 \\
26 \cdot 2 \\
68 \cdot 2 \\
74 \cdot 2 \\
17 \cdot 5 \\
32 \cdot 2\end{array}$ & $\begin{array}{l}272 \\
256 \\
307 \\
774 \\
138 \\
765 \\
419 \dagger \\
132 \\
178\end{array}$ & $\begin{array}{l}0.47 \\
0.68 \\
0.99 \\
1 \cdot 17 \\
0.38 \\
0.78 \\
0.74 \\
0.27 \\
0.22\end{array}$ & $\begin{array}{l}0 \cdot 20 \\
0 \cdot 28 \\
0 \cdot 34 \\
0 \cdot 16 \\
0 \cdot 19 \\
0 \cdot 09 \\
0 \cdot 21 \\
0 \cdot 13 \\
0 \cdot 18\end{array}$ & $\begin{array}{l}1.15 \\
1.06 \\
1.05 \\
1.03 \\
0.69 \\
0.87 \\
0.98 \\
0.65 \\
1.46\end{array}$ \\
\hline
\end{tabular}

* Repeat studies after excision of gastrin-producing tumour.

$\dagger$ Significantly different from basal output values $(P<0.05) ; \ddagger P<0.02$.

(1) preceding the meal; and (2) preceding the betazole test. The basal outputs represented in Figs. 1 and 2 and Table 3 are those measured before the meal. However, they were similar to those measured before the betazole test (mean relative difference: $7.8 \pm 1.6 \%$, mean \pm SE) indicating the good reproducibility of our measurement technique.

\section{STATISTICAL ANALYSIS}

Statistical comparisons were performed by Student's paired $t$ test, after conversion of individual output values to their natural logarithm to approximate a normal distribution (Dixon and Massey, 1969). Mean relative difference of basal outputs in duplicate studies was calculated by the formula:

$$
\frac{1 \text { st study-2nd study }}{\text { mean of two studies }} \times 100
$$

\section{Results}

The fasting, postprandial, and post-betazole acid outputs of each patient are shown by Figs. 1 and 2 . In the patients with higher fasting acid output (cases 1, 3, 4, and 6), ingestion of the meal caused a profound decrease in acid output, which returned to basal levels later in the postprandial period. In these patients (except for case 1), the basal and 'maximal' post-betazole acid outputs were similar. In the two other gastrinoma patients (cases 2 and 5), the fasting acid output was much lower and ingestion of the meal produced an early increase in acid output which was similar to their post-betazole 'maximal' acid outputs (well above basal outputs). Later, during the second or third postprandial hours, transient decreases in acid output below the fasting rate were noted in each patient.

For the six patients considered as group (Table 3), the average postprandial acid output was $46.3 \%$ lower than the basal output $(\mathrm{P}<0.05)$, whereas the average peak postprandial output did not differ significantly from basal. The secretory volume output paralleled the acid output and therefore little change between the fasting and postprandial acid/volume output ratios was noted (Table 3). The pepsin output also decreased transiently after the meal but, in contrast to the acid and secretory volume output, the peak postprandial pepsin output was significantly higher than the basal output $(P<0.05)$. The acid/pepsin output ratio fell correspondingly.

The intragastric $\mathrm{pH}$ increased after ingestion of the meal and gradually returned over a period of two hours to fasting values (Fig. 3). The titratable acidity followed an almost reciprocal pattern (Fig. 3). There was no relationship between the postprandial serum gastrin concentration, which remained similar to or even higher than fasting levels (Table 1), and the change in gastric acid output.

In the two patients who were restudied postoperatively, the fasting gastric acid output decreased profoundly (Fig. 1). This was accompanied by restoration of a normal gastrin and secretory response to the meal (Fig. 1) and by a marked decrease in fasting and postprandial acid/pepsin ratios (Table 3).

\section{Discussion}

To our knowledge, inhibition of gastric acid output by food in patients with the Zollinger-Ellison syndrome due to gastrinoma has not been previously reported. This observation has several pathophysiological and clinical implications.

Ingestion of the meal in all gastrimona patients with marked basal hypersection (cases 1, 3, 4, and 6) produced marked inhibition of gastric acid and secretory outputs. Invariably, however, the gastric 

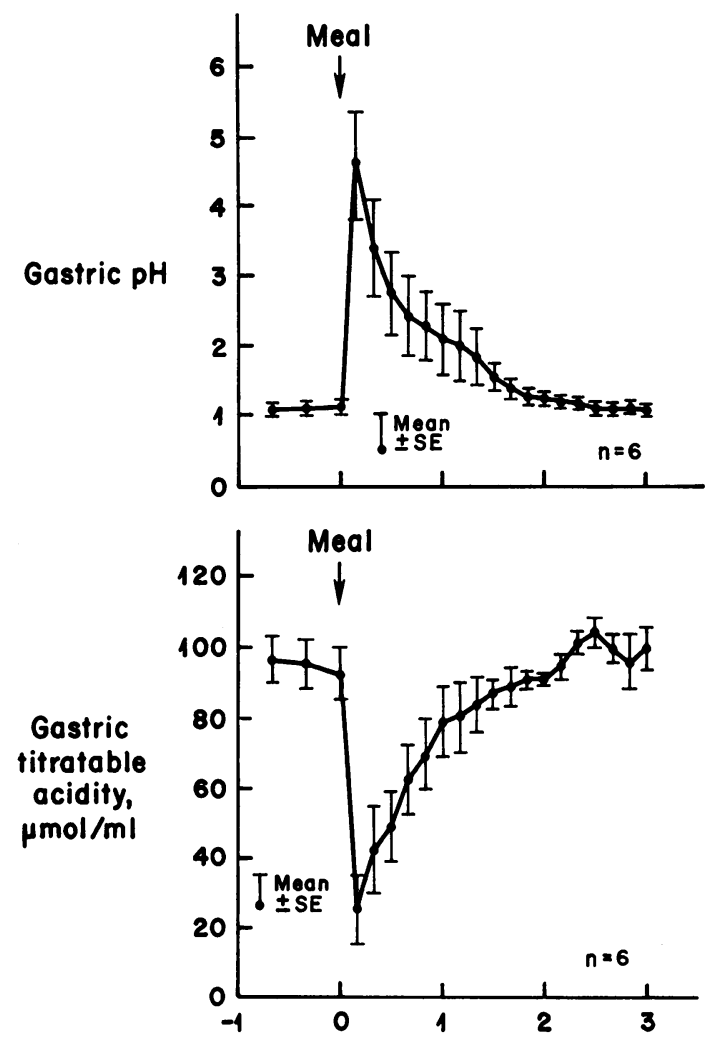

Hours

Fig. 3 Intragastric $\mathrm{pH}$ and titratable acidity before and after meals in patients with gastrinoma. Note that approximately two hours passed before mean postprandial values returned to basal (fasting) levels.

secretory rate returned later in the postprandial period to the fasting rate, suggesting that whichever inhibitory effects were triggered by food were transient and present only while the bulk of the meal remained in the gastrointestinal tract undergoing digestion and absorption. Further, in most of these patients, fasting gastric acid outputs approximated 'maximal' (after betazole) secretory rates suggesting that their stomachs (as it has been described in other patients with gastrinoma) (Isenberg et al., 1973) were almost 'maximally' stimulated, making the decrease observed after the meal even more remarkable.

The pattern of gastric secretory response to a meal observed in these patients with gastrinoma is just opposite to that found under similar experimental conditions in healthy individuals (Malagelada et al., 1976b), in patients with normogastrinaemic, idiopathic duodenal ulcer (Malagelada et al., 1977) and in the two gastrinoma patients who were studied again after successful excision of their gastrinproducing tumour. In each of these, food triggers a marked increase in acid output that later returns to the basal level.

An intermediate-type pattern of response (between that observed in normogastrinaemic individuals and in those with gastrinoma and marked basal hypersecretion) was observed in cases 2 and 5 who had only moderately increased basal secretion. We speculate that in these patients the meal elicited two antagonistic actions: one stimulatory, which acted synergistically with their hypergastrinaemia and drove acid output up initially toward the 'maximal' secretory rate and another inhibitory which tended to counterbalance the effect of sustained hypergastrinaemia and reduce acid output down to and even below the fasting secretory rate. These contrasting effects of the meal manifested a relative predominance of one versus the other at different times during the postprandial period, causing the fluctuating pattern in acid output observed by us.

Interestingly, pepsin outputs (unlike gastric acid and volume) increased significantly above fasting outputs at some time during the postprandial period and, further, excision of the gastrin-producing tumour markedly reduced fasting and postprandial acid to pepsin ratios. These observations support Bader and Bonfils' (1969) claim that patients with gastrinoma have lower than normal fasting pepsin/ acid ratios because of the relatively weak pepsinstimulatory capacity of gastrin.

The mechanism of meal-induced inhibition of gastric acid output in the Z-E syndrome due to gastrinoma remains speculative, particularly since neurohormonal mechanisms responsible for physiological postprandial acid-inhibitory feedback remain largely undefined. Food-triggered inhibitory mechanisms apparently antagonised the stimulatory action of gastrin on parietal cells, because serum immunoreactive gastrin concentrations (reflecting near autonomous neoplastic gastrin secretion) did not decrease postprandially. The strength of these inhibitory forces was such that, at times, postprandial acid outputs before and after excision of the tumour were similar in contrast to the large differences observed in fasting acid output (Fig. 1). Of the known neurohormonal inhibitory mechanisms, those elicited by food components, particularly fat-released 'enterogastrones' (Johnson and Grossman, 1971), are the most likely ones for explaining the net inhibitory effect caused by the meal in our patients with gastrinoma, because they could be expected to operate postprandially counterbalancing the continuous stimulus provided by the hypergastrinaemia. In contrast, acid-triggered inhibitory 
mechanisms, such as secretin release, seem less likely to have an important role because they would be expected to act primarily during fasting, when unbuffered acid is continuously delivered into the duodenum. Our observations underline the interest of examining physiological mechanisms operating under pathological conditions. Further studies are needed to characterise the specific mediators involved.

There are also relevant clinical implications to our findings which are emphasised by comparing the different responses to meals observed in patients who have Z-E syndrome with those who have idiopathic, normogastrinaemic duodenal ulcer. Thus, in gastrinoma, ingestion of a meal often reduced acid output, enhancing the acid buffering and dilution by the meal itself. In contrast, in normogastrinaemic duodenal ulcer, acid buffering and dilution by the meal may be met by a powerful and persistent surge in acid output (Longstreth et al., 1977; Malagelada et al., 1977). Consequently, despite much higher interprandial gastric secretory rates, early postcibal acidity in some patients with Z-E syndrome resembles that found in idiopathic duodenal ulcer. Benefits from meal-induced inhibition of gastric acid output received by the unoperated, metabolically compensated patient with gastrinoma may help in explaining the maintenance of body weight or the excess body weight observed in our patients.

The author wishes to thank Dr V. L. W. Go for his advice and for performing the serum gastrin determinations in his laboratory. He also thanks Mrs Judith Duenes, Ms Ruth Bolton, Ms Cathy DeVos, and Mr Richard Tucker for technical help and Ms Gaurdis Grube for secretarial assistance.

\section{References}

Bader, J. P., and Bonfils, S. (1969). Biological diagnosis of the Zollinger-Ellison syndrome. In Non-Insulin-Producing Tumors of the Pancreas: Modern Aspects on ZollingerEllison-Syndrome and Gastrin, pp. 41-48. Edited by $L$. Demling and R. Ottenjann. Thieme: Stuttgart.

Dixon, W. J., and Massey, F. J., Jr. (1969). Introduction to Statistical Analysis. McGraw-Hill: New York.

Isenberg, J. I. (1973). Gastric secretory testing. In Gastrointestinal Disease: Pathophysiology, Diagnosis, Management, pp. 536-554. Edited by M. H. Sleisenger and J. S. Fordtran. Saunders: Philadelphia.

Isenberg, J. I., Walsh, J. H., and Grossman, M. I. (1973). Zollinger-Ellison syndrome. Gastroenterology, 65, 140-165.

Johnson, L. R., and Grossman, M. I. (1971). Intestinal hormones as inhibitors of gastric secretion. Gastroenterology, 60, 120-144.

Longstreth, G. F., Go, V. L. W., and Malagelada, J.-R. (1977). Postprandial gastric, pancreatic, and biliary response to histamine $\mathrm{H}_{2}$-receptor antagonists in active duodenal ulcer. Gastroenterology, 72, 9-13.

Malagelada, J.-R., Holtermuller, K. H., Sizemore, G. W., and Go, V. L. W. (1976a). The influence of hypercalcemia on basal and cholecystokinin-stimulated pancreatic, gallbladder, and gastric functions in man. Gastroenterology, 71, 405-408.

Malagelada, J.-R., Longstreth, G. F., Deering, T. B., Summerskill, W. H. J., and Go, V. L. W. (1977). Gastric secretion and emptying after ordinary meals in duodenal ulcer. Gastroenterology, 73, 989.994.

Malagelada. J.-R., Longstreth, G. F., Summerskill, W. H. J., and Go, V. L. W. (1976b). Measurement of gastric functions during digestion of ordinary solid meals in man. Gastroenterology, 70, 203-210.

Sizemore, G. W., Go, V. L. W., Kaplan, E. L., Sanzenbacher, L. S., Holtermuller, K. H., and Arnaud, C. D. (1973). Relations of calcitonin and gastrin in the ZollingerEllison syndrome and medullary carcinoma of the thyroid. New England Journal of Medicine, 288, 641-644. 